\title{
Marek Stawecki \\ University of Szczecin marekstawecki@op.pl \\ Transferring real estate by means of a tender by local government units and the State Treasury
}

\begin{abstract}
The Act of 21 August 1997 on real estate management specifies two modes in which real estate which is property of the State Treasury or of a local government unit can be transferred or given in perpetual usufruct - a tender and non-tender mode. The real estate resources are the basic assets element of the above-mentioned entities. They may be used for the purposes of development and organised investment activity, in particular for the construction of residential housing as well as implementing other public purposes.
\end{abstract}

A tender procedure has been specified in the Polish law. A tender is the most optimal way to commit public property. The objective of this instrument consists in transactions involving public real estate according to universally applicable rules. It is a way which gives the greatest guarantee of security in terms of transferring immovable property assets.

Key words:

tender, real estate, transfer, State Treasury, local government unit

\section{Introduction}

The Act of 21 August 1997 on real estate management specifies the following cases allowing transfer of real estate assets which are property of local government units or the State Treasury - a tender and non-tender mode. The above also needs to be applied to the State Treasury or a local government unit transferring the right to perpetual usufruct. ${ }^{1}$

The aim of this paper is to present detailed procedures of the implementation of tenders for public real estate in Poland. The research method employed in this study involves an analysis of legal acts and judicial decisions. A tender is a solution giving the greatest guarantee of security in terms of transferring public property, though not flawless.

As a rule the tender mode is applied. ${ }^{2}$ Non-tender transfer is an exception from the former. The option to apply the said mode occurs only in situations specifically identified in the statute. It is not possible to extend the interpretation of the regulation included in Article 28(1)

Dz. U. (Journal of Laws) of 1997 no. 115 item 741, hereinafter referred to as REMA.

2 M.J. Nowak, Z. Tokarzewska-Żarna, Gospodarka nieruchomościami w gminie. Kluczowe problemy prawne, Warsaw 2017, p. 7. 
REMA. This is because the regulation in question allows transferring property in a non-tender way only in cases specified in the act on real estate management, as referred to in Article $37(2)(1-18)$ of the said act. Moreover, one needs to note that applying the non-tender mode is admissible also where the subject of sale involves immovable property designated for residential housing or immovable property designated for public purposes other than those listed. However, it is essential that the latter should be carried out by the entity for whom these will be statutory objectives. Moreover, incomes of these entities should be fully designated for carrying out statutory activity. Analysing the issues of non-tender transfer one cannot forget real estate developed on the basis of a construction permit. Nevertheless, the above concerns a situation where the sale of real estate is requested by the entity who is its lessee or user on the basis of a contract executed for the period of minimum ten years. Opting for a non-tender mode of transfer lies in the above-mentioned case with the voivode, with the minister for construction by way of an ordinance, or with substantively competent commune council, poviat council or voivodship assembly by way of a relevant resolution.

All issues relating to a sale through must be reflected in the notice. These are requirements for both the sale of an ownership right and the sale of perpetual usufruct. The above is grounded in Article 28(2) REMA.

The elements the notice in question must comprise include: identification of the real estate for sale, specifying the starting price which is the consequence of the value established earlier by an asset valuer in the form of a valuation report. Moreover, the notice must not omit the issue of the tendering security (5 to 20 percent of the starting price) and bid increments (minimum 1 percent of the starting price). One needs to note the requirement of informing potential parties interested in taking part in the tender on the manner and conditions for paying the price after their offer has been successful. It is also necessary for the notice to include information about the real estate's purpose, e.g. in the local land use plan or in the decision on development terms and conditions, if such a decision has been issued. If, however, the subject of transfer involves a right to perpetual usufruct then it becomes necessary to specify the period for which this right is to be established. In the context of the said right (i.e. perpetual usufruct), it is also necessary to specify the type of development and time periods for real estate development. One cannot omit the perpetual usufructary's obligation to maintain buildings and devices in due condition in the course of the usufruct.

It is inadmissible to specify previously not stipulated requirements after making the tender notice public.

Each tender should result in a conclusion of a contract in the form of a notarial deed. A report is drawn up for each tender, which is the basis for formulating the said contract. The requirements discussed above must be reflected in the notice as well as in the contract.

\section{Tender mode}

In order to introduce public property into trading it is necessary to place it on the list of real estate designated for transfer, usufruct, lease, lease with the right to collect fruits or lending for use. The above aims to observe the principle of transparency since the list and the notice 
are its reflection. This involves transparency in trading in public property, specifically real estate which is property of the State Treasury or of local government units. One of tasks of the said list consists in creating opportunities for stakeholders to take efforts to acquire rights to an item included in the list. This means a possibility of putting forward a relevant claim to listed real estate before it is sold. What is more, the above entails the authorised entities' exercising their right of pre-emption. ${ }^{3}$

The regulation of Article 35(1) REMA stipulates how to publically announce information about the list which should be posted for 21 days at the premises of the competent office. Additionally, it needs to be published on the office's websites. It needs to be noted that a poviat administrator carrying out a public administration task passes the list onto the voivode in order for it to be published. This also applies to immovable property which is the property of the State Treasury. This occurs as the above-mentioned official performs public administration tasks. In turn, it is the Voivode's task to publish the list in the Public Information Bulletin for 21 days. Moreover, he should make the information public by announcing it in local press with a reach covering at least a poviat. It entails a poviat relevant due to the location of the property in question. The list refers to property transferred both in a tender and non-tender manner. It needs to be noted that until the property is placed on the real estate list it does not function in transactions. It is because it is the owner who decides about designating the real estate for trading and about the form of this trading. ${ }^{4}$

Pursuant to the regulation of Article 35(1b) REMA the obligation to be placed on the discussed list does not apply to real estate designated for lease, lease with the rights to collect fruits or lending for use for a time period of up to 3 months. The above is subject to change if the contract is to be extended to a period exceeding 3 months. In such a case being placed on the list becomes obligatory regardless of whether it refers to new contracts concerning the same item concluded between the same entities or a change in the contract resulting in extending the time period to exceed three months. Information specified in Article 35(2)(14) REMA must be obligatorily provided in all lists. The said regulation stipulates that these include: a land and mortgage register, signifying real estate according to the cadastre, size of the real estate, real estate's description, information on the real estate's purpose and its development. It is necessary to specify whether the immovable property is designated for transfer or for perpetual usufruct, or whether it is designated to be leased or leased with the right to collect fruits, to be given in usufruct or to be lent for use.

It becomes necessary to indicate such elements as the price of the immovable property or the amount of the first charge in the case of perpetual usufruct or percentage rates of annual fees. Moreover, it is necessary to specify the time frame for the development. It is obligatory to name the period in order for authorized entities to exercise their right of pre-emption pursuant to Article 34(2)(1) and (2) REMA.

Failure to comply with the above will constitute invalidity of the act in law i.e. a contract concluded in violation of the said obligation. ${ }^{5}$ It needs to be pointed out that a change in the purpose should result in a re-announcement of the list and in making it publically available. ${ }^{6}$

3 J. Siegień, Ustawa o gospodarce nieruchomościami. Komentarz, Jaktorów 1999, p. 78.

Ibidem.

Judgment of the Supreme Court of 11 May 2005, III CK 564/04.

Judgment of the Voivodship Administrative Court in Białstok of 26 October 2006, II SA/Bk 491/06. 
Causing violation of regulations concerning pre-emption rights results in general liability. The above applies both to the State Treasury and local government units. The liability referred to above is liability for damages. This means that the entity whose pre-emption right has been violated is entitled to claim compensation under terms and conditions set forth above. The above can be also sought by an entity who conducted administrative proceedings to establish the validity of acquisition of immovable property for a local government unit or the State Treasury. Transferring real estate disregarding the pre-emption right of former owners or their heirs when acquiring the real estate leads to invalidity of a contract of transferring such reals estate. ${ }^{7}$ Liability under Article 36 REMA is of an exclusive nature and does not allow questioning the validity of a contract concluded in disregard to the pre-emption right or questioning the act in law under Article 59 of the Civil Code. ${ }^{8}$ Such an approach serves the security in trading in real estate property and also narrows down the circle of entities authorized to exercise the pre-emption right. This refers, however, to certain entitled persons. The entity whose right has been violated should specify the basis for its claim. Moreover, they must specify the amount of the damage. It needs to be noted that in the situation in question one can pursue compensation regarding losses or lost benefits. ${ }^{9}$

\section{Tender and non-tender mode. Basic rule and exceptions}

The main rule for transferring real estate by local government units or the State Treasure is to do it by means of a tender. ${ }^{10}$ Failure to comply with it should result in invalidity of the contract.

Preparing a report on the tender, which is a basis for drawing up a contract, will give the specified entity an acquisition claim regarding the real estate in question. ${ }^{11}$ Public entities are not obliged under the provisions of the law to transfer public immovable property. Their relevant bodies decide whether to do so and for what price. There is also no regulation that would grant anybody a property transfer claim. ${ }^{12}$ There are, nevertheless, ways to withdraw from the tender-mode of the transfer. The said situations are stipulated in regulations. It needs to be noted what these cases must not be interpreted as extending the regulation as they are exceptions from the rule. ${ }^{13}$ Therefore, the tender is the main mode. Non-tender disposition of immovable real estate is an exception from the rule prescribed in regulations. ${ }^{14}$ This concerns in particular Article 37(2) REMA which includes a list of possibilities of transfer excluding the tender mode. At the moment the article in question comprises twenty situations. A few of them can be mentioned, e.g. transferring to entities that perform charity, care or cultural activities, for purposes not related to gainful activity. However, should the sale to such an entity

7 Judgment of the Supreme Court of 20 January 1998, I CKN 368/97, OSNC 1998/9, item 143.

8 Judgment of the Supreme Court of 25 March 2004, II CK 268/03.

9 G. Bieniek, Komentarz do ustawy o gospodarce nieruchomościami. Vol. I (działy I i II ustawy), Warsaw-Zielona Góra 1998, p. 170.

10 Judgment of the Supreme Administrative Court of 11 May 2011, I OSK 203/11.

11 Judgment of the Supreme Administrative Court of 22 March 2011, I OSK 2110/10.

12 Judgment of the Supreme Administrative Court of 23 February 2011. I OSK 1729/10.

13 Judgment of the Supreme Administrative Court of 21 March 2007, I OSK 1998/06.

14 Judgment of the Voivodship Administrative Court in Wrocław of 8 July 2009, III SA/Wr 86/09. 
be planned for gainful purposes then the tender mode becomes obligatory. Another frequent case involves transferring real estate in order to expand adjoining property. This should entail improvement of development of the parcel for which the transfer is done. However, it is essential that the transferred item cannot be used as self-contained property as the tender mode would need to be applied then.

The non-tender mode should not be used to burden the buyer with costs of preparing the property for transfer as it concerns contract elements within the competence of the transferor's organ. ${ }^{15}$

The real estate management act specifies rules for organizing tenders for the sale of immovable property. Pursuant to Article 38 of the said act they are carried out by competent authorities. The term competent authorities encompasses poviat administrators, presidents of towns with poviat rights or executive bodies of local government units with territorial jurisdiction. In the context of the above one must remember the minister competent for matters of construction, land use planning and housing as he is competent to announce, organize and conduct tenders in cases stipulated in Article 57(1) REMA and for real estate included in the list referred to in Article 60(2)(1) REMA. ${ }^{16}$

Initiating the procedure to transfer real estate by means of a tender results in the establishment of a civil law relationship between specified entities: the competent authority, i.e. the tender's organizer, and its participants. ${ }^{17}$ a tender notice should include the following: information included in the content of the list, time and place of the tender. Information should also be provided on the tender's terms and conditions and, should the need for subsequent tenders arise, information about dates of previous tenders. ${ }^{18}$

The discussed tender notice which is a reflection of the principle of transparency should be placed on the notice board of a relevant office. Such information also needs to be publically announced by means usually adopted in a given community and on the said office's website. Non-application of transfer through tender after the notice has been made public is admissible only for important reasons. The above means that it is not admissible to do so without having a reason to cancel the tender. A decision to cancel a tender entails the competent authority's exercise of the right resulting from the act in question. An administrative court shall not review the issue of refusal to repeat the tender procedure as a result of a complaint. ${ }^{19}$

Only the activity concerning the conduct of the tendering procedure is challengeable. It is not admissible here to bring a case before an administrative court. Cancellation of a tender is not challengeable. ${ }^{20}$

Where the tender ends unsuccessfully the competent organ should conduct a second tender. This should take place after 30 days have passed, but no later than 6 months after closing the previous one.

The regulations do not stipulate an obligation to conduct the second tender. The competent authority then faces a decision whether to organize a subsequent tender or to withdraw

15 Judgment of the Voivodship Administrative Court in Wrocław of 11 June 2014, II SA/Wr 242/14.

16 E. Bończyk-Kucharczyk, Ustawa o gospodarce nieruchomościami. Komentarz, Warsaw 2018, p. 356.

17 Resolution of the Supreme Court of 2 August 1994, III CZP 96/94, OSNC 1995/1, item 11.

18 S. Kalus, Ustawa o gospodarce nieruchomościami. Komentarz, Warsaw 2012, p. 345.

19 Order of the Supreme Administrative Court of 22 February 2010, I OSK 207/10.

20 Order of the Voivodship Administrative Court in Łódź of 7 December 2007, II SA/Łd976/07. 
from the idea of sale a through tender. Withdrawing from a transfer by means of a tender does not close the way to the non-tender mode. However, if a decision about a second tender is taken then the starting price may be lowered maximally to $50 \%$ of the starting price from the first tender. The above does not mean that the price in question cannot be increased or left at the current level. If the second tender too ends unsuccessfully then the competent authority again faces the choice - whether to conduct another tender (on terms applicable in the second one) or to attempt to transfer the real estate by means of negotiated procedure. The above shows that it is impossible to conduct negotiated procedure after the first "unsuccessful tender". Legal protection in a situation where an entity conducts negotiations in violation to good customs involves the possibility to pursue claims for compensation under Article 72(2) of the Civil Code. ${ }^{21}$

It is an extremely important issue that in the negotiated procedure the price is established in the amount not lesser than $40 \%$ of the value of the real estate. Where subsequent tenders are organized there is no need to draw up a list of real estate. It needs to be noted that the valuation report drawn up by an asset valuer remains valid for 12 months. However, it is possible for a relevant asset valuer to "update" the document in question. The above may take place after the said period has passed. Failure to observe the rules set forth in the statute in question, thus violation of procedures, results in invalidity of such an agreement concluded in disregard to the procedures. ${ }^{22}$ Reports on tenders and negotiated procedures are the basis for the parties to claim conclusion of contracts. ${ }^{23}$

The act on real estate management empowers the competent authority to choose between four forms of tender. When the aim of the tender is to achieve the highest possible price then an oral tender should be chosen. A written tender should be opted for if its objective is to get the most favourable offer. ${ }^{24}$

The above mentioned procedures may be open or restricted. The former occurs when the terms and conditions set out in the tendering procedure may be satisfied only by a certain number of entities. The regulation in question applies to entities who may be participants to the procedure.

The regulation of Article 40(3) REMA provides the competent authority with an opportunity to choose between a restricted or open procedure. The organizer referred to above also has considerable discretion in terms of establishing terms and conditions of the tendering procedure. ${ }^{25}$ Nevertheless, the said entity should exercise its relevant rights in moderation and with caution as it may result in a situation where no one or only one person will be able to meet the incorrectly established requirements. Such a situation may lead to a conclusion that one is dealing with a tender ending unsuccessfully. This occurs e.g. where no entity paid the tendering security or where in the course of the tendering procedure no-one offered a price for bid increments. The above concerns an oral tender. For written tenders, the reason to state that the tendering procedure ended unsuccessfully includes a situation e.g. where the tender committee concluded that all of the offers fail to meet the procedure's requirements. It needs

21 Judgment of the Voivodship Administrative Court in Wrocław, III SA / Wr 519/07.

22 Judgment of the Supreme Court of 11 May 2005, III CK 562/04.

23 Resolution of the Supreme Court of 2 August 1994, III CZP 96/94, OSNCP 1995/1, item 11.

24 A. Prusaczyk, Ustawa o gospodarce nieruchomściami. Komentarz, Warsaw 2017, p. 196.

25 G. Bieniek, Ustawa o gospodarce nieruchomościami. Komentarz, Warsaw 2005, p. 224. 
to be noted that it is not possible to recognize a tender as closed unsuccessfully if the buyer has been established in its course yet no final contact has been signed e.g. in the form of a notarial deed. Any participant has the right to appeal against the result of the tender. The time period to do so is set to 7 days. In the course of an analysis of the appeal in question the competent authority informs about possible irregularities. ${ }^{26}$ Acknowledging the complaint will entail either a repetition of the tender or a decision to annul it. However, where the real estate in question is transferred before the appeal is examined, only the court will become competent to solve the analysed issue. An administrative court will become competent when all avenues prescribed for in Article 40(5) REMA have been explored. In such a case the above mentioned authority for legal protection will mainly focus on allegations concerning failure to comply with regulations on the mode of conducting the tender. The said authority may not undertake to substantively assess the legitimacy of rulings of the tender committee as regards submitted offers. ${ }^{27}$ One needs to point to the fact that a voivode's decision resulting in a cancellation has the character of a civil law statement on avoidance of legal effects of the tendering procedure. The above also refers to relevant declarations of local government units about cancelling the tender. ${ }^{28}$

If a tender participant unsatisfied with the decision about cancelling the tender, after an ineffective appeal, files a complaint with the court, then this court is obliged to assess independently the validity of the organization of the tender. The above will also apply to specifying legal effects which are consequences of the above-mentioned assessment. Questioning the result of the tender should proceed according to regulations included in Article 40(4) REMA. The district court, in the course of procedure concerning the establishment of a land and mortgage register and an entry of an ownership right does not conduct an inspection and does not specify whether the tender was organized correctly. Moreover, it does not analyse its course or rights taken by a participant other than the real estate owner. ${ }^{29}$

\section{Obligations following the tender}

The successful tenderer should conclude a contract with the transferor in the form of a notarial deed. In view of the above, the competent authority is obliged to notify the said tenderer within 21 days from the decision taken in the tendering procedure about the place and time of executing the contract. The said time period resulting from the notice should not be shorter than 7 days from the date of serving the notice on the buyer. Analysing the above one question needs to noted. It the entity who is the buyer fails to sign the contract without a justification then it must expect a sanction of losing the tendering security paid before to the tender's organizer. The requirement here involves informing, duly and in advance, about its place and time in the notification, which must include information about this right. The above also means that the real estate buyer may request that the organizer should make a declaration of intent

26 Order of the Supreme Administrative Court of 7 June 2011, I OSK 891/11.

27 Resolution of the Supreme Court of 25 April 1996, III CZP 36/96, OSNC 1996/9, item 115.

28 Order of the Supreme Court of 30 October 1990, I CZ 265/90, OSNCP 1991/10-12, item 132.

29

Resolution of the Supreme Court of 13 January 1995, III CZP 172/94, OSNC 1995/4, item 65. 
necessary to conclude the contract in question. When adjudicating this claim it should be established whether or not there are premises for the tender's organizer's withdrawing from the conclusion of the contract. ${ }^{30}$

Article 41(2) REMA specifies only one requirement for losing the tendering security. It involves unaccounted for absence at the place and time of signing the contract. In such a situation the transferor, without a confirmation that his account has been credited with payment, despite the fact that the buyer produces a document confirming the money transfer, should establish a different time in order to perform the obligation in question. ${ }^{31} \mathrm{~A}$ reason justifying the byer's withdrawal from placing a signature under the contract may include defects in the course of tendering activities. Noticed defects of the object of the transfer, both physical and legal, may also be a reason. Following the closure of the tendering procedure a mutual obligation arises between the organizer and the person established as the buyer, the aim of which is to execute a contract. Regulations concerning general provisions in the question of contractual obligations need to be applied to the above. Moreover, they need to be combined with regulations on the effects of failure to carry out contractual obligations. The above gives a basis to conclude whether the buyer has the right to withdraw from signing the contract if he notices defects in the tendering procedure. He does not have to first execute a contract in the form of a notarial deed and then withdraw from it or avoid legal effects of a submitted declaration of intent. ${ }^{32}$ If then the entity called the buyer of the subject-matter of the tender became entitled to withdraw from the contract or to avoid legal effects of a submitted declaration of intent on account of facts known to them before the signing of the contract, then they may withdraw from executing the contract. In such a case the competent authority will not exercise the right to keep the tendering security.

Based on Article 42 REMA the currently applicable Resolution of the Council of Ministers of 14 September 2004 on the manner and mode for holding tenders and negotiated procedures for the transfer of real estate was passed. ${ }^{33}$ The said act establishes rules for organizing tenders. Moreover, the regulation specifies the issue of conducting negotiated procedures which may be held after a second tender ends unsuccessfully. It also establishes rules concerning the tendering security and notices which reflect the principle of transparency. The said act does not avoid such significant issues as the tender committee, the tender report and questioning tender activities. It also points to regulations on the terms and conditions for organizing a restricted tender or on conducting negotiated procedures.

It needs to be highlighted that if the organizer fails to observe the time periods specified in Article 39 REMA and does not organize subsequent tenders or negotiated procedures, they will be obliged to hold the tender again which should be deemed as first. The implementing rule in question specifies in detail who can participate in a tender. It will include entities who paid the tendering security into the account of the organizer in due time, i.e. no later than three days before the tender. Moreover, the regulation specifies issues related to the amount of the tendering security in question, i.e. from $5 \%$ to $20 \%$ of the starting price. The choice here lies with the competent authority. The question of the date for the payment of the tendering

30 E. Bończyk-Kucharczyk, Ustawa o gospodarce..., p. 367.

31 Judgment of the Supreme Court of 11 February 2009, V CSK 326/08.

32 Judgment of the Supreme Court of 19 March 2003, I CKN 148/01.

33 Dz. U. (Journal of Laws) of 2014 item 1490. 
security is also reflected in the discussed act, i.e. it should be specified in a way which makes it possible for the tender committee to affirm, no later than 3 days before the tender, that the tendering security was indeed paid in. Whereas when it comes to returning the tendering security it is done no later than three days after the tender ends. The term ending should be understood as i.a. cancelling, closing, annulling but also ending unsuccessfully. The tendering security form the best offer will be calculated into the bid amount. Thus, the buyer is obliged to pay the purchasing price less the discussed tendering security before the date of singing the notarial deed.

In line with the discussed regulation, the tender's organizer should publically announce the tender notice no later than 30 days before the established date of the tender. Whereas where immovable property whose starting price is higher that the equivalent of EUR 100,000 is concerned, no later than 2 months before the established date of the tender. Whereas if the starting price in question is higher that EUR 10,000 then a notice excerpt is published in press with a reach no smaller than the poviat. This means a periodical issued at least once a week at least 30 days before the established date of the tender. This concerns a poviat relevant for the location of the real estate in question. However, if, in line with $\$ 6(5)$ of the said regulation, the starting price of the real estate to be transferred exceeds EUR 100,000 then the notice excerpt is publically announced at least 2 months before the established date of the tender in daily press with a nation-wide reach. Where the starting price is above EUR 10 million, the notice is announced at least twice. However, it needs to be pointed out that the first notice excerpt is publically announced no later than 2 months before the established date of the tender. The second one at least 30 days before the relevant date. ${ }^{34}$ The tender report is a very important document reflecting all activity carried out in the course of the tendering procedure. This document is prepared in three copies - one is given to the successful tenderer and the other two to the organizer. It is this document that evidences i.a. bid increments proposed by individual tender participants in its course. It is signed at the end by all members of the committee and by the buyer. A great role in these activities is played by the tender committee who, among other things, analyse the documents produced by tenderers such as confirmation of payment of the security, IDs. This document is submitted to a notary's office in order for a contract in the form of a notarial deed to be drawn up. The choice of the notary is left to the buyer's discretion. The prevailing view in the judicial decisions of the Supreme Court involves an opinion that notifying the tenderer about his offer being successful results in the creation of a civil law obligation relationship between the organizer and the tenderer, which in turn results in an obligation to make a declaration, in a prescribed legal form, about concluding a contract which is the object of the tender. ${ }^{35}$ In accordance with the discussed regulation, questioning tendering activities by a participant is done through the tender's organizer. However, in the event of failure to observe the time specified for appeal referred to earlier or if a complaint is treated as unfounded then information about the outcome of the tendering procedure is made publically available by the organizer by posting it at the premises of a competent authority for 7 days ( $\$ 12(1)$ of the discussed regulation).

34 S. Źróbek, R. Źróbek, J. Kuryj, Gospodarka nieruchomościami z komentarzem do wybranych procedur, Katowice 2011, p. 133.

35 Judgment of the Supreme Court of 19 March 2003, I CKN 148/01. 


\section{Conclusion}

The rules for local government units and the State Treasury managing immovable property are regulated by the Real Estate Management Act.

The resource of real estate belonging to the said entities is the main element of public assets. Employing it is mostly supposed to serve public purposes. This concerns primarily provision of public services. However, in the context of the above one cannot avoid undertaking investment activity or other activity focused on stimulating local development.

The sale of real estate owned by the State Treasury or local government units or giving it in perpetual usufruct may be done in a non-tender way. However, transfer of real estate by means of a tender is the rule.

The tender is the main tool used for an efficient operation of trading in public real estate. It is the most optimal way to manage public property, though not flawless. A tender, as one of the ways to execute a contract, is multilateral. Exclusion proceedings are another essential feature that cannot be omitted. The entity which is in a strict relationship with the subject-matter of the tender is primarily focused on achieving best possible benefits by selecting the best offer and removing others. ${ }^{36}$ The course of the tendering procedure has been strictly specified in the Polish law. The aim of this paper was to present detailed procedures of holding tenders for public real estate in Poland. The research method employed in the study involved an analysis of legal acts and the established line of judicial decisions.

The research presented in the paper is based on an analysis of the Polish law in terms of trading in public real estate. The act on real estate management is of fundamental importance in this matter. A discussion of basic elements of tendering activities, institutions such as the tendering security, the starting price, lowering the starting price, forms of tenders or notices proved that regulations in terms of trading in public real estate give a considerable dose of security in terms of managing public property. The tendering security, an element characteristic to a tender, serves to secure the organizer - by specifying the assets assessment in order to select potential buyers. The said entity accepts the tendering security before the emergence of the legal relationship which is to emerge as a result of the tendering procedure, thus securing the performance of potential obligations of a future counterparty. Transfer by means of a tender is based on a mechanism fundamental to free market economy - competition. In places where there is no competition this manner of concluding a contract cannot actually operate properly. A tender, being a restriction of freedom of contract, makes it impossible for public entities to freely and thoughtlessly select counterparties, thus protecting public property against irrational disposal. In the real estate management act the tender is the rule and the non-tender mode is exception from this rule.

Thanks to the analysis a conclusion can be made which confirms the statement referred to above that a tender is a method which gives the greatest guarantee of security in terms of transferring public property. 


\section{Literature}

Bieniek G., Komentarz do ustawy o gospodarce nieruchomościami. Vol. I (działy I i II ustawy), Warsaw-Zielona Góra, 1998.

Bieniek G., Rudnicki S. Nieruchomości. Problematyka prawna, Warsaw 2011.

Bieniek G., Ustawa o gospodarce nieruchomościami. Komentarz, Warsaw 2005.

Bończyk-Kucharczyk E., Ustawa o gospodarce nieruchomościami. Komentarz, Warsaw 2018. Kalus S., Ustawa o gospodarce nieruchomościami. Komentarz, Warsaw 2012.

Nowak M.J., Tokarzewska-Żarna Z., Gospodarka nieruchomościami w gminie. Kluczowe problemy prawne, Warsaw 2017.

Prusaczyk A., Ustawa o gospodarce nieruchomściami. Komentarz, Warsaw 2017.

Siegień J., Ustawa o gospodarce nieruchomościami. Komentarz, Jaktorów 1999.

Źróbek S., Źróbek R., Kuryj J., Gospodarka nieruchomościami z komentarzem do wybarnych procedur, Katowice 2011.

\section{Legislative acts}

Act of 21 August 1997 on real estate management (Dz. U. (Journal of Laws) of 1997 no. 115 item 741).

Resolution of the Council of Ministers of 14 September 2004 on the manner and mode for holding tenders and negotiated procedures for the transfer of real estate (Dz. U. (Journal of Laws) of 2014 item 1490).

\section{Judicial decisions}

Judgment of the Supreme Administrative Court of 15 October 2002, I SA 632/02. Judgment of the Supreme Administrative Court of 11 May 2011, I OSK 203/11. Judgment of the Supreme Administrative Court of 22 March 2011, I OSK 2110/10. Judgment of the Supreme Administrative Court of 23 February 2011, I OSK 1729/10. Judgment of the Supreme Administrative Court of 21 March 2007, I OSK 1998/06. Judgment of the Supreme Court of 11 May 2005, III CK 564/04. Judgment of the Supreme Court of 20 January 1998, I CKN 368/97, OSNC 1998/9, item 143. Judgment of the Supreme Court of 25 March 2004, II CK 268/03.

Judgment of the Supreme Court of 11 May 2005, III CK 562/04. Judgment of the Supreme Court of 11 February 2009, V CSK 326/08. Judgment of the Supreme Court of 19 March 2003, I CKN 148/01. Judgment of the Supreme Court of 19 March 2003, I CKN 148/01. Judgment of the Supreme Court of 4 November 1982, II CR 407/82, OSNCP 1983/7, item 97. Resolution of the Supreme Court of 2 August 1994, III CZP 96/94, OSNC 1995/1, item 11. Resolution of the Supreme Court of 2 August 1994, III CZP 96/94, OSNCP 1995/1, item 11. 
Resolution of the Supreme Court of 25 April 1996, III CZP 36/96, OSNC 1996/9, item 115.

Resolution of the Supreme Court of 13 January 1995, III CZP 172/94, OSNC 1995/4, item 65.

Order of the Supreme Court of 30 October 1990, I CZ 265/90, OSNCP 1991/10-12, item 132.

Order of the Supreme Administrative Court of 22 February 2010, I OSK 207/10.

Order of the Supreme Administrative Court of 7 June 2011, I OSK 891/11.

Judgment of the Voivodship Administrative Court in Białystok of 26 October 2006, II SA/Bk 491/06.

Judgment of the Voivodship Administrative Court in Wrocław 8 July 2009, III SA/Wr86/09.

Judgment of the Voivodship Administrative Court in Wrocław 11 June 2014, II SA/Wr 242/14.

Judgment of the Voivodship Administrative Court in Wrocław, III SA/Wr 519/07.

Order of the Voivodship Administrative Court in Łódź of 7 December 2007, II SA/Łd976/07. 